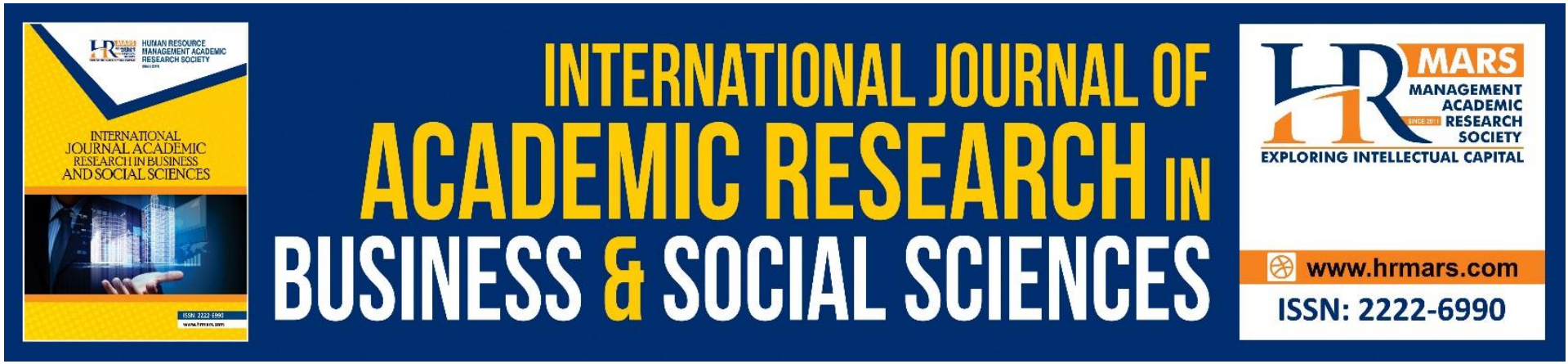

\title{
The Effect of Transformational Leadership on Employees' Performance in Malaysia's Public Sector
}

\section{Aminah Ahmad}

To Link this Article: http://dx.doi.org/10.6007/IJARBSS/v10-i11/8363

DOI:10.6007/IJARBSS/v10-i11/8363

Received: 12 September 2020, Revised: 16 October 2020, Accepted: 19 November 2020

Published Online: 28 November 2020

In-Text Citation: (Ahmad, 2020)

To Cite this Article: Ahmad, A. (2020). The Effect of Transformational Leadership on Employees' Performance in Malaysia's Public Sector. International Journal of Academic Research in Business and Social Sciences, 10(11), 1396-1407.

\section{Copyright: (c) 2020 The Author(s)}

Published by Human Resource Management Academic Research Society (www.hrmars.com)

This article is published under the Creative Commons Attribution (CC BY 4.0) license. Anyone may reproduce, distribute, translate and create derivative works of this article (for both commercial and non-commercial purposes), subject to full attribution to the original publication and authors. The full terms of this license may be seen at: http://creativecommons.org/licences/by/4.0/legalcode

Vol. 10, No. 11, 2020, Pg. 1396 - 1407

Full Terms \& Conditions of access and use can be found at http://hrmars.com/index.php/pages/detail/publication-ethics 


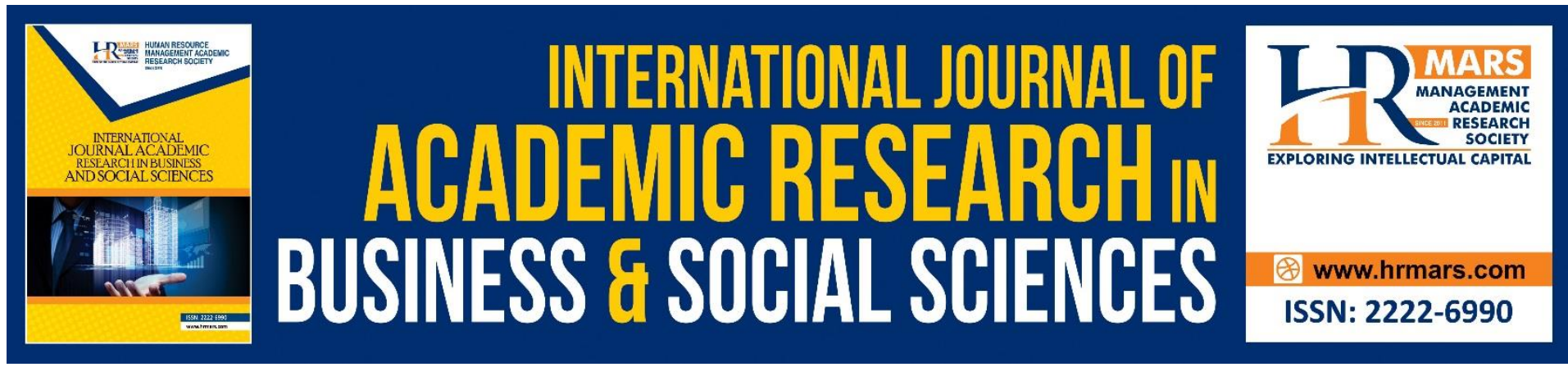

\title{
The Effect of Transformational Leadership on Employees' Performance in Malaysia's Public Sector
}

\author{
Aminah Ahmad \\ Arshad Ayub Graduate Business School, Universiti Teknologi MARA, 40450 Shah Alam, \\ Selangor Darul Ehsan, Malaysia \\ Sylvia Nabila Azwa Ambad \\ Faculty of Business \& Management, Universiti Teknologi MARA, 88997 Kota Kinabalu,
} Sabah, Malaysia

\section{Syed Jamal Abdul Nasir Syed Mohd}

Arshad Ayub Graduate Business School, Universiti Teknologi MARA, 40450 Shah Alam, Selangor Darul Ehsan, Malaysia

\section{Nelson Lajuni}

Faculty of Business, Economics and Accountancy, Universiti Malaysia Sabah (UMS), 88400 Kota Kinabalu, Sabah, Malaysia

\begin{abstract}
Employee performance is one of the main management topics that received substantial attention from scholars and practitioners. Thus, this study aims to investigate the effect of transformational leadership on employees' performance in Malaysia's public sector. A total of 286 sets of questionnaires are manually collected from a public sector department. The data are then analyzed by utilizing Partial Least Squares-Structural Equation Modeling (PLSSEM) using SmartPLS 3.3.2. This study found that transformational leadership has a significant positive influence on employee performance in Malaysia public service sector. This paper contributes to the body of knowledge on management literature by developing and empirically testing a causal model of transformational leadership on employee performance in the context of Malaysia's public sector. The findings also suggest the importance of leadership styles that focuses on improving employees' development, process-oriented, a commitment based on trust and expectations, which motivate employees to perform beyond expectation.
\end{abstract}

Keywords: Transformational Leadership, Employee Performance, Public Service Sector, Task Performance, Contextual Performance 


\section{Introduction}

The public sector plays a crucial role in providing various fundamental services to the public. It is responsible for conducting all activities within the state and for providing essential services for the people of a country. Communities and other stakeholders who need the services of the government are increasingly demanding excellent and quality service, which they usually received from the business sector (Napitupulu et al., 2017; Khalid, 2020). The level of public satisfaction with services provided by the public sector is often used as an indicator of the performance of the public sector organization, whereby the employees play a crucial role in ensuring the standard and quality of the public sector performance. Thus, employees' performance has been identified as an important aspect of the public sector because it reflects the quality of services and government performance (Aarabi et al., 2013; Abzari \& Ghujali, 2011). Consequently, employees need to work more efficiently and effectively to increase the productivity and progress of the organization they represented.

Employees' performance in any government institution is mostly determined or evaluated based on the leadership style implemented by the leaders responsible for ensuring the achievement of the short term and long-term objectives by the employees in their respective departments or areas of operation (Kazeem, 2014). The literature discussed several styles of leadership, and transformational leadership is one of the most used styles in organizations to manage the change (Sarros and Santora, 2001; Kejriwal and Krishnan, 2004; Indrawati, 2014). Typically, transformational leaders inspire workers to 'go the extra mile' by raising workplace morale and fostering motivation; a process which ultimately benefits both workers and their organization. Studies have shown that transformational leadership is generally practised and accepted in many industries (e.g., banking, military and hospitality) and countries with different culture settings (e.g., Malaysia, Australia, and Taiwan) (Ozaralli, 2003; Brian \& Lewis, 2004; Xirasagar, 2008; Ivey \& Kline, 2010; Ling et al., 2011; Jogulu \& Ferkins, 2012; Dai et al., 2013; Abd Rahman et al., 2013; Hardy, 2014; Ag Budin and Wafa, 2015; Katou, 2015). However, very few studies examined the effect of transformational leadership on employee performance in the public sector setting (Ramayah, Samat, \& Lo, 2011). Nevertheless, it is essential to comprehend how the concepts of transformational leadership and employee performance are experienced and interpreted from the perspective of the public sector. Therefore, this study intends to explore and examine the effect of transformational leadership on employee performance and to determine how it relates to the performance of employees in Malaysia's public sector.

\section{Literature Review}

Employees' job performance can be defined as the total expected value that an individual brings to the organization of the discrete behavioural episodes, which carries out over a standard period of time (Motowidlo \& Kell, 2012). It can also be defined as how efficiently employees accomplish their duties (Torlak \& Kuzek, 2019). Employee performance is usually measured through multiple dimensions (Pradhan \& Jena, 2017; Deslie, 2015). Also, employee performance is usually measured based on the employee's knowledge, skills, expertise, and behaviour necessary to perform a job (Pawirosumarto et al., 2017). Most organizations greatly emphasis on employees' job performance as it is a crucial element in achieving sustainable competitive advantage.

Meanwhile, Transformational Leadership can be defined as a situation when one or more person engages with each other, whereby the leaders and followers raise each other's level of motivation; hence, creating a transforming effect on both leaders and followers (Venkat, 
2012; Burn 1978). According to Bass and Avolio (1997), transformational leadership has four dimensions, namely idealized influence, inspirational motivation, intellectual stimulation, and individualized consideration. Transformational leadership focuses on improving employees' development, process-oriented, and a commitment based on trust and expectations; thus, motivating employees to perform beyond expectation (Hater \& Bass, 1988). Transformational leaders inspire followers to go beyond their self-interests, and these leaders have an extraordinary effect on followers (Robbins \& Judge, 2017).

As public sector government agencies strive to provide services to citizens, senior leaders responsible for achieving and improving performance must successfully manage complex bureaucracies (Kim, 2015). The public sector leaders lean toward transactional versus transformational leadership strategies. The public sector provides a less conducive framework to practice transformational leadership, as public leaders are bound by financial regulations and constraints and sometimes by the arbitrary nature of political demands and by unforeseen events (Hargrove \& Glidewell, 1990; Mughal, 2019).

A study conducted in Malaysia reported that Malaysia is known to be collectivistic in nature (Hofstede, 1991), which suggest that Malaysian leaders are more likely to emphasize on maintaining supportive relationships more than rewarding individual performance. Bass (1990) suggested that the transformational leadership style is more appropriate for collectivistic culture than other styles of leadership. It was expected that the transformational leadership style would make a better contribution to employees' individual performance than transactional leadership style.

In their study, Chen et al. (2009) stated that transformational leadership theory identifies transformational leadership as an important driver in stimulating employee performance, whereby employee performance is also supported by employee creativity in the organization to ensure the set goals are achieved. The motivation for employee performance in this type of leadership style is based on the reward and punishment system. The theory assumes that employees are usually driven by rewards and punishments, which are also dependent on the employees' performance. The rewards are meant to motivate employees to increase their performance to a higher level, which is meant to move the organization to a higher level. The punishments are meant to ensure that employees meet the expected standard of performance within the organization and to prevent them from getting poor results. The relationship of the managers and subordinates in this theory is relational, whereby the achievement of given goals and organizational expectations by subordinates is determined by monitoring techniques implemented by the managers to ensure performance efficiency.

As the capacity of public leaders to bring about change is increasingly questioned, public agencies have come under pressure to transform and innovate. More research is needed to identify how leaders who promote innovation, creativity, and adaptability affect the performance of public organizations (Fernandez \& Rainey, 2006; Fernandez, 2008). Constant improvement of organizations and individuals encourages leaders to innovate, evaluate risks as opportunities, and tackle the status quo. This raises the significance of how transformational leadership contributes and reacts to public agencies' environment and how it might reorganize them (Avolio \& Bass, 1988).

The previous study by Mokgolo and Modiba (2012) showed that transformational leaders reduce conflict in organizations and improve productivity and outcomes in the public sector. Additionally, there is a growing body of evidence that recognized the importance of transformational leadership in the public sector (Van Slyke \& Alexander, 2006; Wright \& Pandey, 2009). Groenewald and Ashfield (2008) suggested that transformational leaders 
could reduce the influence of uncertainty, raise the performance of employees to an acceptable standard, and achieve the goals of employees and organizations. Furthermore, Vera and Crossan (2004) added some characteristics of transformational leaders in the public sector, such as helping employees to unlearn past routines and supporting creative solutions to complex problems. Dumdum et al. (2002) asserted that transformational leadership behaviors are at least as common and useful as a bureaucratic mechanism in public organizations.

\section{Methodology and Data Analysis}

This study was a quantitative approach, and our respondents were officers from the public sector in Malaysia. A non-probability sampling technique known as purposive sampling was applied to ensure our data for this survey were indeed from reliable sources. In this study, different measures were used for measuring the variables. A model by Bass and Avolio (1999) was adopted for measuring the Transformational Leadership style. The model comprised 12 items. Meanwhile, the model by William and Anderson (1991) was adopted for measuring employee performance, which consists of 12 items. In total, 24 items were used in this study. A 7-point Likert scale ranging from "strongly disagree" (1) to "strongly agree" (7) was adopted to measure both the independent and dependent variables. We use $\mathrm{G}^{*}$ power 3.0 software to estimate the sample size (Faul et al., 2007) by applying the effect size of $\mathrm{f} 20.15$, $\alpha$ error pro 0.05 , and power Gf 0.95 with one tested predictor. Thus, we only need 89 respondents as our minimum sample for this study. Nevertheless, we distributed 300 questionnaires, and subsequently collected 286 completed questionnaires analysed using the survey method.

\section{A. Framework and Hypothesis Development}

Researcher conducted a review of related literature on risk management practices, and the review revealed that transformational leadership (TL) was the catalyst of employee performance (EP). Transformational leadership was labelled as an exogenous variable, and employee performance the endogenous variable in this study. This study proposes a conceptual model, as shown in Figure 1 . We formulate a hypothesis that corresponds with the objective of this study.

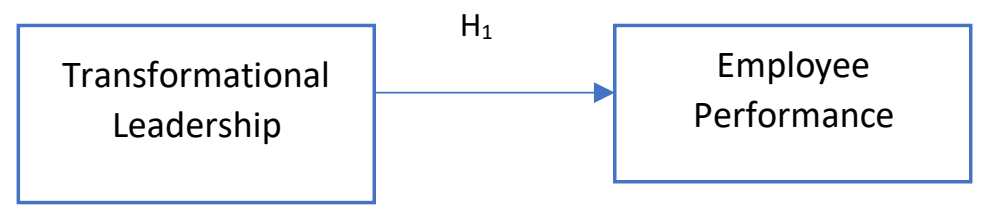

H1: Transformational leadership positively influences employee performance.

\section{Figure 1: Conceptual Framework}

\section{Findings}

The respondents were mostly females (53.8\%), while males were slightly lower (46.2\%). The range of age was: $21-35$ years (44.4\%), 36-45 years (35.3), 46-55 years (13.6), 55 years and above $(5.6 \%)$ and $18-20$ years (1\%). Most of the respondents (29.4\%) have between $11-20$ years of experience in their respective positions, and the rest have 1-5 years of experience (21.7\%), more than 20 years of experience $(21.0 \%)$, more $6-10$ years $(19.6 \%)$, while only $8.4 \%$ of respondents have less than one year of experience. 


\section{A. Assessment of Measurement Model}

Table 2 demonstrates the construct reliability (CR) and convergent validity testing. Hair et al. $(2010,2014)$ stated that when the constructs' value of the average variance extracted (AVE) reached at least 0.5 or more, the convergent validity is deemed sufficient. The AVE lowest threshold of 0.50 indicates that convergent validity is adequate (Hair et al., 2014); it means all items of the respective constructs explain at least $50 \%$ of the variance. The results confirm that the variables under investigation have high internal consistency (Roldán \& SánchezFranco, 2012) and an acceptable average variance extracted (AVE) to validate the convergent validity (Hair et al., 2017). Four indicators were deleted as the loadings led to lower AVE that violates the minimum value of 0.500 (Hair et al., 2017). Almost all indicators show satisfactory loadings' values that are consistent with the threshold value of 0.708 , as suggested by Hair et al. (2017) (except for EP5, EP8, and EP11; these loadings were not deleted as long as the AVE value is $\geq 0.500$ ). The Cronbach's alpha (CA) and composite reliability (CR) values for both constructs possessed high internal consistency, whereby, transformational leadership (TL) was 0.869 (CA), and 0.896 (CR) and employee performance (EP) was 0.963 (CA) and 0.966 (CR), respectively. Meanwhile, the average variance extracted (AVE) for each construct was more than 0.5 . Thus, we conclude that both constructs have satisfactory convergent validity as the indicators could explain more than $50 \%$ of the constructs' variance as presented in Table 2.

Table 2: Measurement Model Assessment

\begin{tabular}{|c|c|c|c|c|c|c|}
\hline Construct & Item & Loadings & CR & CR & AVE & CV (Ave $>0.5)$ \\
\hline \multirow[t]{8}{*}{ EP } & EP1 & 0.769 & 0.869 & 0.896 & 0.521 & Yes \\
\hline & EP11 & 0.598 & & & & \\
\hline & EP2 & 0.832 & & & & \\
\hline & EP3 & 0.737 & & & & \\
\hline & EP4 & 0.774 & & & & \\
\hline & EP5 & 0.609 & & & & \\
\hline & EP6 & 0.788 & & & & \\
\hline & EP8 & 0.625 & & & & \\
\hline \multirow[t]{12}{*}{ TL } & TL1 & 0.755 & 0.963 & 0.966 & 0.703 & Yes \\
\hline & TL10 & 0.816 & & & & \\
\hline & TL11 & 0.789 & & & & \\
\hline & TL12 & 0.835 & & & & \\
\hline & TL2 & 0.840 & & & & \\
\hline & TL3 & 0.845 & & & & \\
\hline & TL4 & 0.798 & & & & \\
\hline & TL5 & 0.886 & & & & \\
\hline & TL6 & 0.890 & & & & \\
\hline & TL7 & 0.874 & & & & \\
\hline & TL8 & 0.860 & & & & \\
\hline & TL9 & 0.865 & & & & \\
\hline
\end{tabular}

Next, HTMT criterion was examined to check the discriminant validity, as presented in Table 3 (Ringle et al., 2020). In order to assess discriminant validity, this study applied Henseler's 
(2015) heterotrait-monotrait ratio of correlations criterion. The findings reveal that the discriminant validity was well-specified at HTMT0.85 (Diamantopoulos \& Siguaw, 2006). The results suggest that the correlation values corresponding to the respective constructs follow the most conservative criterion (HTMT.85), which implies that the discriminant validity issue is not a concern. The findings specified that it is appropriate to proceed with the structural model assessment to examine the hypothesis of the study as there is no issue of multicollinearity between items loaded on different constructs in the outer model.

Table 3: HTMT Criterion

\begin{tabular}{|l|l|l|}
\hline & $\mathrm{EP}$ & $\mathrm{TL}$ \\
\hline $\mathrm{EP}$ & & \\
\hline $\mathrm{TL}$ & 0.215 & \\
\hline $\begin{array}{l}\text { Criteria: Discriminant validity is established at } \\
\text { HTMT0.85 (Diamantopoulos \& Sigauw, 2006) }\end{array}$ \\
\hline
\end{tabular}

\section{B. Assessment of Structural Model}

We conducted a 5000-bootstrap resampling of data to examine the hypothesis (Hair et al., 2017) and used two-tailed test, and a significance level at 0.05 (at 95\% confidence level). According to Hair et al. (2014), path coefficient estimated the path relationship between endogenous variables in the structural model. In Table 4, the Beta value for the path coefficient specifies that transformational leadership positively influences employee performance. As shown in Table 4, the proposed relationship ( $\mathrm{H} 1)$ significantly influences employee performance in Malaysia's public sector. Specifically, the study found support for $\mathrm{H}_{1}$ where the path coefficient result between transformational leadership and employees' performance showed a positive relationship with a beta of $0.235, p<0.000, \mathrm{LLCl}=0.163, \mathrm{ULCl}$ $=0.284$ is also deemed significant.

Table 4: Path Coefficients

\begin{tabular}{|l|l|l|l|l|l|l|l|}
\hline Direct Effect & Beta & S.E. & t-value & p-value & LLCI & ULCl & Decision \\
\hline TL -> EP & 0.235 & 0.048 & 5.077 & 0.000 & 0.163 & 0.284 & Supported \\
\hline
\end{tabular}

Table 5 shows the assessment of model quality. researcher assessed the effect size $\left(f^{2}\right)$, the coefficient of determination $\left(R^{2}\right)$, and the predictive relevance $\left(Q^{2}\right)$ of exogenous variables (on the endogenous variable in this study. Transformational leadership reveal a small effect size $f^{2}$ on the employees' performance (Cohen, 1988 ) as shown by $f^{2}=0.059$. Hence, implying that transformational leadership is a weak construct to influence employee performance. The coefficient of determination represented by $R^{2}$ that explains whether transformational leadership could unveil employee performance indicates a small effect (Chin, 1998). The $R^{2}$ value for employee performance was 0.055 , suggesting that transformational leadership explains employee performance weakly.

Multicollinearity between indicators was assessed as well. The indicators satisfied the VIF value, and there were consistently below the threshold value of 5.0 (Hair et al., 2014) and 3.3 (Diamantopoulos \& Siguaw, 2006). Thus, it can be concluded that collinearity issues did not exceed the critical levels for both variables; and therefore, are not an issue for the estimation of the PLS path model. The predictive relevance values for the dependent variable was weak, 
as specified by the value of 0.024 , indicating that transformational leadership is considered weak at predicting employee performance among civil servants in the public sector in Malaysia, as presented by $Q^{2}$ using the blindfolding procedure (Hair et al., 2017).

Table 5: Model Quality Assessment

\begin{tabular}{|l|l|l|l|l|}
\hline Direct Effect & $\mathrm{f}^{2}$ & $\mathrm{R}^{2}$ & $\mathrm{VIF}$ & $\mathrm{Q}^{2}$ \\
\hline TL -> EP & 0.059 & 0.055 & 1.000 & 0.024 \\
\hline Lateral Collinearity: VIF 3.3 or higher (Diamantopoulos \& Siguaw, 2006) \\
\hline$R^{2} \geq 0.26$ consider Substantial (Cohen, 1989) \\
\hline$F^{2} \geq 0.26$ consider Substantial (Cohen, 1989) \\
\hline$Q^{2}>0.00$ consider large (Hair, 2017) \\
\hline $0.02 \leq Q^{2}<0.15$ : weak predictive power \\
\hline $0.15 \leq Q^{2}<0.35$ : moderate predictive power \\
\hline$Q^{2} \geq 0.35:$ strong predictive power \\
\hline
\end{tabular}

\section{Discussion}

The result shows that the hypothesis is supported, the finding show that transformational leadership positively influences employee performance $(\theta=0.235, p<0.000)$. This result agrees with the findings of Rita et al. (2018), who stated that transformational leadership has a positive correlation with employee performance. The results of this study are also supported by other previous studies, one of which is Syaifuddin (2016), who suggested that transformational leadership has a positive and significant effect on performance. The results of this study are in a similar vein with results of several past studies (Pawirosumarto et al., 2017; Musa et al., 2018; Manzoor et al., 2019; Wardana et al., 2018; Mughal, 2019), which reveal that transformational leadership has a positive and significant effect on employee performance.

\section{Conclusion}

The current study aims to investigate the effect of transformational leadership style on employee performance. Consistent with the theory, transformational leadership is found to be a predictor to employee performance. Therefore, transformational leadership is an important driver in motivating employee performance. The four characteristics in leadership, namely idealized influence, inspirational motivation, intellectual stimulation, and individualized consideration, augmented employees' motivation to perform better.

Although this study contributes to the literature, it is important to take into consideration several limitations. The model used in this study is rather simplistic. Future studies replicating this study should consider using a mediator and moderator variables in their research, such as empowerment, job satisfaction, and organizational commitment, among others.

\section{Corresponding Author}

Aminah Ahmad.

Arshad Ayub Graduate Business School, Universiti Teknologi MARA, 40450 Shah Alam, Selangor Darul Ehsan, Malaysia.

Email: aaaminah772gmail.com 


\section{Reference}

Aarabi, M. S., Subramaniam, I. D., \& Akeel, A. B. A. A. B. (2013). Relationship between motivational factors and job performance of employees in Malaysian service industry. Asian Social Science, 9(9), 301-310.

Abzari, M., \& Ghujali, T. (2011). Examining the impact of internal marketing on organizational citizenship behavior. International Journal of Marketing Studies, 3(4), 95.

Adi, M. N. M., Noor, H. M., Rahman, A. G. A., \& Yushuang, T. (2013). The influence of leadership style on job satisfaction among nurses. Asian Social Science, 9(9), 172-178.

Ag Budin, D. K., \& Wafa, S. A. (2015). The relationship between culture and leadership style preference among Malay-Brunei, Bajau and Kadazan-Dusun community in Sabah, Malaysia. Journal of Management Development, 34(10), 1202-1210.

Bass, B. (1988). The inspirational processes of leadership. Journal of management development, 7(5), 21-31.

Bass, B. M., \& Avolio, B. J. (1990). The implications of transactional and transformational leadership for individual, team, and organizational development. Research in organizational change and development, 4(1), 231-272.

Bass, B. M., \& Avolio, B. J. (Eds.). (1994). Improving organizational effectiveness through transformational leadership. Sage.

Brain, K., \& Lewis, D. (2004). Exploring leadership preferences in multicultural workgroups. Leadership \& Organization Development Journal, 25(3), 263-278.

Burns, J. M. (1978). Leadership. NY: Harper \& Row.

Chin, W. (1998). Commentary: Issues and Opinion on Structural Equation Modeling. MIS Quarterly, 22(1), 7-16.

Cohen, J. (1988). Statistical power analysis for the behavioral sciences (2nd ed.). Hillsdale, NJ: Lawrence Earlbaum Associates.

Deslie, N. (2015). The impact of leadership style on employee performance. Unpublished manuscript.

Diamantopoulos, A., \& Siguaw, J. A. (2006). Formative versus reflective indicators in organizational measure development: A comparison and empirical illustration. British journal of management, 17(4), 263-282.

Dumdum, U. R., Lowe, K. B., \& Avolio, B. J. (2013). A meta-analysis of transformational and transactional leadership correlates of effectiveness and satisfaction: An update and extension. Transformational and charismatic leadership: The road ahead, 35-66.

Faul, F., Erdfelder, E., Lang, A. G., \& Buchner, A. (2007). G* Power 3: A flexible statistical power analysis program for the social, behavioral, and biomedical sciences. Behavior research methods, 39(2), 175-191.

Fernandez, S. (2008). Examining the effects of leadership behavior on employee perceptions of performance and job satisfaction. Public Performance \& Management Review, 32(2), 175-205.

Fernandez, S., \& Rainey, H. G. (2006). Managing successful organizational change in the public sector. Public administration review, 66(2), 168-176.

Groenewald, A., \& Ashfield, G. (2008). When leaders are also explorers. The Star Workplace, 7, 56.

Hair Jr, J. F., Hult, G. T. M., Ringle, C., \& Sarstedt, M. (2016). A primer on partial least squares structural equation modeling (PLS-SEM). Sage publications.

Hair, J. F., Black, W. C., Babin, B. J., Anderson, R. E., \& Tatham, R. (2006). Multivariate data analysis. Uppersaddle River. 
Hair, J. F., Hult, G. T. M., Ringle, C. M., Sarstedt, M., \& Thiele, K. O. (2017). Mirror, mirror on the wall: a comparative evaluation of composite-based structural equation modeling methods. Journal of the Academy of Marketing Science, 45(5), 616-632.

Hardy, C. A. (2014). Transformational leadership: a quasi-experimental study. Leadership and Organization Development Journal, 35(1), 38-53.

Hargis, M. B., Watt, J. D., \& Piotrowski, C. (2011). Developing leaders: Examining the role of transactional and transformational leadership across business contexts. Organization Development Journal, 29(3), 51-68.

Hargrove, E. C. (1990). Impossible jobs in public management. University Press of Kansas.

Hater, J. J., \& Bass, B. M. (1988). Superiors' evaluations and subordinates' perceptions of transformational and transactional leadership. Journal of Applied psychology, 73(4), 695.

Hayduk, L. A., \& Littvay, L. (2012). Should researchers use single indicators, best indicators, or multiple indicators in structural equation models?. BMC medical research methodology, 12(1), 1-17.

Hofstede, G., Hofstede, G. J., \& Minkov, M. (1991). Cultures and organizations: Intercultural cooperation and its importance for survival. Software of the Mind London: McGrawHill.

Indrawati, N. K. (2014). Management by inspiration: Implementation of transformational leadership on business at pondok Pesantren, Sunan Drajat. Procedia-Social and Behavioral Sciences, 115, 79-90.

Ivey, G. W., \& Kline, T. J. (2010). Transformational and active transactional leadership in the Canadian military. Leadership \& Organization Development Journal, 31(3), 246-262.

Jogulu, U., \& Ferkins, L. (2012). Leadership and culture in Asia: The case of Malaysia. Asia Pacific Business Review, 18(4), 531-549.

Katou, A. A. (2015). Transformational leadership and organisational performance. Employee Relations, 37(3), 329-353.

Khalid, N. (2020). Artificial intelligence learning and entrepreneurial performance among university students: evidence from malaysian higher educational institutions. Journal of Intelligent \& Fuzzy Systems, (Preprint), 1-19.

Kim, S., \& Yoon, G. (2015). An innovation-driven culture in local government: do senior manager's transformational leadership and the climate for creativity matter?. Public Personnel Management, 44(2), 147-168.

Krishnan, V. R. (2012). Transformational leadership and personal outcomes: empowerment as mediator. Leadership \& Organization Development Journal, 33(6), 550-563.

Lo, M. C., Ramayah, T., \& Min, H. W. (2009). Leadership styles and organizational commitment: a test on Malaysia manufacturing industry. African Journal of Marketing Management, 1(6), 133-139.

Manzoor, F., Wei, L., Nurunnabi, M., Subhan, Q. A., Shah, S. I. A., \& Fallatah, S. (2019). The impact of transformational leadership on job performance and CSR as mediator in SMEs. Sustainability, 11(2), 436-450.

Mokgolo, M. M., Modiba, M., \& Mokgolo, P. (2012). Transformational leadership in the South African public service after the April 2009 national elections. Journal of Human Resource Management, 10(1), 1-9.

Musa, Y., Danjuma, S., Alaba, F. A., Ritonga, R., Muhammad, A., Djajanto, L., \& Herawan, T. (2018). An Impact of Transformational Leadership on Employees' Performance: A Case Study in Nigeria. In Information Systems Design and Intelligent Applications, 708-719. 
Napitupulu, S., Haryono, T., Riani, L. A., Sawitri, H. S. R., \& Harsono, M. (2017). The impact of career development on employee performance: an empirical study of the public sector in Indonesia. International Review of Public Administration, 22(3), 276-299.

Ozaralli, N. (2003). Effects of transformational leadership on empowerment and team effectiveness. Leadership \& Organization Development Journal, 24(6), 335-344.

Pawirosumarto, S., Sarjana, P., \& Muchtar, M. (2017). Factors affecting employee performance of PT.Kiyokuni Indonesia. International Journal of Law and Management, 59(4), 602-614.

Pradhan, R. K., \& Jena, L. K. (2017). Employee performance at workplace: Conceptual model and empirical validation. Business Perspectives and Research, 5(1), 69-85.

Ramayah, T., Samat, N., \& Lo, M. (2011). Market orientation, service quality and organizational performance in service organizations in Malaysia. Asia-Pacific Journal of Business Administration, 3(1), 8-27.

Ringle, C., Wende, S., \& Will, A. (2020). SmartPLS 3.3.2. Retrieved from http://www.smartpls.com.

Rita, M., Payangan, R. O., Rante, Y., Tuhumena, R., and Erari, A. (2018). Moderating effect of organizational citizenship behavior on the effect of organizational commitment, transformational leadership and work motivation on employee performance. International Journal of Law and Management, 60(4), 953-964.

Robbins, S., \& Judge, T. A. (2017). Organizational Behavior. 13th Edition. Essex: Pearson Education Limited.

Saifuddin, H. N., \& Sermsri, S.(2008). Job satisfaction among nurses in Aceh timer district Nanggroe Aceh Darussalam province Indonesia. Science Journal, 38(2), 233-250.

Sarros, J. C., \& Santora, J. C. (2001). The transformational-transactional leadership model in practice. Leadership \& Organization Development Journal, 22(8), 383-394.

Schmitt, N. W., Highhouse, S. E., \& Weiner, I. B. (2013). Handbook of psychology: Industrial and organizational psychology, 12. John Wiley \& Sons Inc.

Torlak, N. G., \& Kuzey, C. (2019), Leadership, job satisfaction and performance links in private education institutes of Pakistan. International Journal of Productivity and Performance Management, 68(2), 276-295.

Van Slyke, D. M., \& Alexander, R. W. (2006). Public service leadership: Opportunities for clarity and coherence. The American Review of Public Administration, 36(4), 362-374.

Vera, D., \& Crossan, M. (2004). Strategic leadership and organizational learning. Academy of management review, 29(2), 222-240.

Wardana, I. M., Utama, I. W. M., \& Astawa, I. P. (2018). Model of local population perception in supporting Coastal Tourism development and planning in Bali. GeoJournal of Tourism and Geosites, 23(3), 873-880.

Williams, L. J., \& Anderson, S. E. (1991). Job satisfaction and organizational commitment as predictors of organizational citizenship and in-role behaviors. Journal of management, 17(3), 601-617.

Wright, B. E., \& Pandey, S. K. (2010). Transformational leadership in the public sector: Does structure matter?. Journal of public administration research and theory, 20(1), 75-89.

Xirasagar, S. (2008). Transformational, transactional and laissez-faire leadership among physician executives. Journal of Health Organization and Management, 22(6), 599613. 
INTERNATIONAL JOURNAL OF ACADEMIC RESEARCH IN BUSINESS AND SOCIAL SCIENCES

Vol. 10 , No. 11, 2020, E-ISSN: $2222-6990$ @ 2020 HRMARS

Yusuf, M. O., Muhammed, U. D., \& Kazeem, A. O. (2014). Management of leadership style: An approach to organizational performance and effectiveness in Nigeria. International Journal of Humanities Social Sciences and Education, 1(2), 17-29. 